\title{
Changing women's roles, changing environmental knowledges: evidence from Upper Egypt
}

\author{
JOHN BRIGGS*, JOANNE SHARP*, NABILA HAMED† AND HODA YACOUB† \\ *Department of Geography \& Geomatics, University of Glasgow, Glasgow G12 8QQ \\ E-mails: jbriggs@geog.gla.ac.uk; jsharp@geog.gla.ac.uk \\ +Unit of Environmental Studies and Development, South Valley University, Aswan, Egypt
}

This paper was accepted for publication in June 2003

\begin{abstract}
The aim of this paper is to investigate the ways in which changing gender roles in a Bedouin community in Upper Egypt, brought about by settlement over the last 20 years on the shores of Lake Nasser, have impacted on the accumulation and development of indigenous environmental knowledges by Bedouin women. The research was carried out among four groups of Ababda Bedouin in the Eastern Desert of Egypt and involved in-depth monthly conversations carried out over a period of 12 months. The main conclusions of the study are that the women of the study area have had to develop new knowledges which, in some cases, are now different from those held by men because of the different economic circumstances in which many find themselves; that these knowledges are fluid, dynamic and ever-changing with their own internal dynamism; and that socially constructed notions of gender are vital in the development process, notions that are sensitive to both men's and women's interests and their interrelationships.
\end{abstract}

KEY WORDS: Egypt; indigenous knowledges, group interviews, gender roles, Bedouin, desert

\section{Introduction}

$\mathrm{D}$ espite the recognition for many years of the vital and pro-active economic contributions of women to household reproduction in developing countries (see, for example, Boserup 1970; Young 1993; Bryceson 1995; and discussions in Desai and Potter 2002), there still seems to be a doubt in some quarters as to the real effectiveness of such contributions. As Varley (2002) reminds us, there is still a loyalty in parts of the 'development community' to the concept of the household as the basic unit of production, based on the assumptions that some sort of decisionmaking consensus exists within the household, and that we can treat a group decision in much the same way as an individual decision. Women, therefore, may be subsumed within the household. The result is that women's economic contributions may be seen to be rather less than they really are, and that women may be seen to have little influence over decisions anyway, and especially so in overtly patriarchal societies. This may be compounded, as Chowdhry (1995) warns, where perceptions exist of rural Third World women being seen as either traditional barriers to modernization and development, or as mere victims without agency subject to decisions taken by husbands, fathers or brothers. In short, there can emerge from this line of thinking a view of rural Third World women as reactionary and conservative.

Such understandings have, of course, not been unchallenged. Women in Development (WID) approaches explicitly acknowledged difference within the household and the power relations that exist within it. Moreover, the economic contributions of women to household reproduction are seen to be both important and separate to those of men (see Young (2002) for a good summary discussion). As a result of this emphasis on household reproduction, and importantly the resources which sustain it, the view has developed among some WID theorists that women might in fact be better custodians of the environment than men. This greater empathy with nature might imply, therefore, a different environmental knowledge base from men, or at least a difference of emphasis within that knowledge. Hence, the Women's Environmental 
Network has argued that '[w]omen's priorities are usually oriented towards the good of the community thus placing more emphasis on the protection of the environment and the resources within it' (quoted in Jackson 1993, 1950). This argument has been taken further by suggestions that an increased women's participation in environmentally oriented development projects may assist in promoting both an empowerment of women and, crucially, a solution to environmental problems (see Jewitt's (2000) critical review). Women are represented not as passive figures blocking progress, but as active agents of change with their own economic and social interests and strengths, which may well be quite independent of those of men. Hence, women become both visible and central in the development process. Clearly, these arguments direct us towards exploring the interrelationships between women's economic contributions to rural societies and their management of natural resources.

However, there are difficulties with WID approaches. The emphasis on women, as in some way economically separate from men, can cause alienation and resentment, and in some cultures may be interpreted as a challenge to the existing (masculinist) social order. Furthermore, conceptually, such approaches can present a singular, somewhat unchanging view of women, rather than recognizing the diversity of daily experiences faced by women. For instance, the idea that women may be better custodians of the environment is based upon a stereotype of woman as nurturer (from her role as mother), rather than through an examination of the material bases of real women's lives. In many cases, this may be true, and women may well demonstrate a sympathetic stewardship over local environmental resources (as may men in other circumstances). But to suggest that this is always the case assumes that women have access to a comprehensive environmental knowledge, and that they are able to practice such knowledges without interference and with undisputed access to land and resources (Jewitt 2000). Thus, as Jackson argues:

There is a need to unpack the idea that women's 'responsibilities' make them environmentally friendly - the responsibility to provide firewood for cooking a meal may lead a woman, when faced with a firewood shortage, to plant a tree but it may also lead her to pull up a wooden fence and burn it, to argue for the purchase of a fuel efficient stove, to insist on the purchase of charcoal, to delegate fuelwood collection to a younger woman in the household or any number of alternative responses.

Jackson 1993, 1958
Because of some of these difficulties with WID, emphasis has moved to gender and development (GAD) approaches which focus explicitly on issues of gender relations, that is, the roles socially expected of both women and men in each circumstance, rather than only focusing on women. They recognize that gender roles can be very different in different places and at different times, and are inherently complex, textured and interwoven. A problematic, however, is the tension between the strategic, but politically difficult, aims of empowerment, to strengthen women's position within society, on the one hand, and the more immediate aims of survival on the other hand, which may have little impact at all on gender relations in society (Moser 1989). Certainly, the longer-term strategic gender aims are more difficult to deliver, and, as such, some feminists are worried that the political aims of empowerment may become lost. A key question, then, in the context of this paper is the extent to which the development of new environmental knowledges by women (and men for that matter) in support of economic production, perhaps even survival, is intertwined with women's empowerment. Certainly, with increased responsibilities for economic output and increased empowerment in household reproduction goes the need to develop new knowledges in support of women's changing roles in household reproduction. Some of these knowledges, be they technical, environmental, market or other knowledges, may be indigenous to the community, others may be acquired from outside the community, whilst others may have developed as mediated or hybridized knowledges.

Little of the recent interest in indigenous knowledge, however, has specifically addressed women's environmental knowledges. There appears to be at least implicitly a masculinist perspective in much of our thinking about indigenous knowledge, an assumption that environmental and technical knowledges in particular lie in the men's domain and are of little relevance to women's everyday lives. This echoes the notion that if skills or knowledges relate to (domestic) household reproduction, then they are predominantly women's knowledges; but if they relate to external economic production, then they are men's knowledge. But this denies women the possibility of managing economic production in their own right, as well as ignoring the fact that women may possess an important set of knowledges from beyond those related to the domestic arena of the household. Indeed, the problem of taking women's indigenous knowledge seriously is further compounded because of the ways in which there has been a general silencing of the indigenous (male) voice anyway, not least because Africans have been all too often represented as 
unscientific exploiters, or even 'pirates', of the natural resource base (MacKenzie 1995; Hobbs 1998). There still exists the view that too many people are irresponsible and profligate in their use of the rangelands, that they have no sense of obligation to others in the community, and that they have little or no conception of resource management (see the pervasive and, in many quarters, still influential view of Hardin (1968)). Hence, if indigenous knowledge is not to be taken seriously anyway, then the marginal position of women in many communities presumably makes their knowledges even less worthy.

Such negative views of indigenous knowledge systems are supported by important critiques. All too often indigenous knowledges seem to be too narrowly focused on issues related to technical knowledges and soil management systems, rather than issues related to the broader natural resource base. Moreover, such knowledges are seen to be too place-specific anyway to be of much use generally, and especially so in relation to the claims of 'universal knowledge' made by formal science. Adams et al. (1994) particularly recognize the spatial heterogeneity of indigenous knowledge and hence warn against overgeneralization. If this is the case, then it is only as a method, not as a body of knowledge, that indigenous knowledge may be readily transferable over space. Other critics argue that indigenous knowledge research often fails to ground itself in its economic, environmental, political or cultural contexts, almost as though it takes place in some timeless, placeless dimension (Bell 1979; Bebbington 1993; McCabe 1990). Indigenous knowledges are frequently charged with being static and unchanging, unlike modern science which is represented as dynamic and ever-changing. Indeed, despite the proliferation of academic work in the field (see, for example, Bellon 1995; Briggs et al. 1998; Lamers and Feil 1995; Maddox et al. 1996; Tiffen et al. 1994; Reij et al. 1996; Sillitoe 1998), there remains a persistent reluctance among many in the development community to embrace these ideas seriously. Formal science still represents a powerful body of knowledge; it is still the language of authority and dominance in many development debates. Indeed, Pretty has observed that the trouble with normal science is that it gives credibility to opinion only when it is defined in scientific language, which may be inadequate for describing the complex and changing experiences of farmers and other actors in rural development' (1994, 38). This represents a particularly difficult set of issues, especially for those advocating the utility of indigenous knowledge and its wider acceptance into development discourses, but a set of issues worth challenging.
Against this background, the paper has two main aims. The first is to explore how women, under conditions of changing resource opportunities, have taken responsibility for developing new environmental knowledges, and modifying existing ones, as part of household economic production. The second is to analyse how such knowledges have been affected by, and indeed have contributed to, changing gender roles, and thus, to an extent, gender relations. The empirical context of this work relates to a community of Bedouin women in the Wadi Allaqi area of the Eastern Desert of southern Egypt (Figure 1). Of particular concern for the community are the challenges created by the new and changed natural resource opportunities produced by the creation of Lake Nasser formed behind the Aswan High Dam in the 1970s. The Bedouin have had to adapt to the new circumstances, and to develop new environmental knowledges in support of their economic activities, and both men and women have been involved. In this context, an understanding of changing gender roles within the community becomes important.

\section{Wadi Allaqi: the study area}

Wadi Allaqi is located about $180 \mathrm{~km}$ south of Aswan in the Eastern Desert of Egypt (Figure 1). It is characterized by a hyperarid environment; rainfall hardly ever falls in the downstream part of the wadi, and an annual average of only $50 \mathrm{~mm}$ is experienced in the hill areas to the east and southeast. Hence, Lake Nasser is a crucial source of reliable water. Small livestock production of sheep and goats comprises a fundamental component of the Bedouin economy in the Eastern Desert, with the other components (camel herding, charcoal production, small-scale cultivation, medicinal plant collection, trading, and, increasingly, wage labour) generally being of lesser importance (Briggs et al. 1993). Traditionally, small livestock production has been dominated by men, and women typically have made only limited inputs. For those Bedouin communities around the shore of Lake Nasser, the success of livestock production is still very dependent on transhumance practices. The flocks are moved from areas on the shore of Lake Nasser, where they are grazed during the late spring, summer and early autumn, to higher areas in the Red Sea Hills and elsewhere in the autumn and winter (Briggs 1995). This takes advantage of grazing resources in these areas which are stimulated by relatively small amounts of winter rain. Although it was common up until about 15-20 years ago for the whole household to move with the flocks, such winter herding of sheep and goats in the Red Sea Hills is now largely only a male 


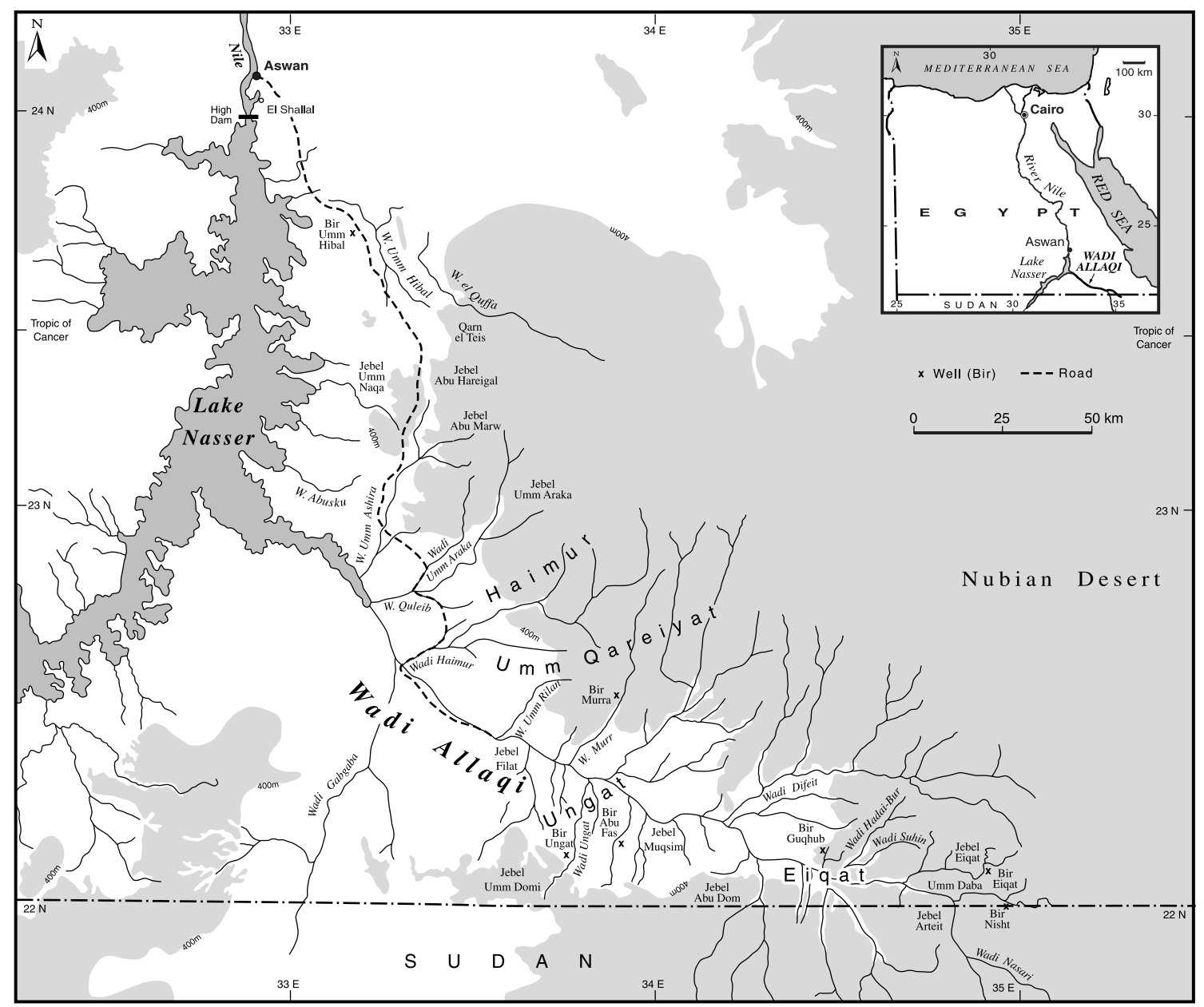

Figure 1 Location of the study area

activity. For the rest of the year, the water from Lake Nasser supports grazing materials around the lakeshore as well as providing a secure supply of water for both humans and animals.

Within the study area, three main Ababda clans are present (Hamedab, Sadenab, and Fashekab), and each is located in a particular geographical area within Wadi Allaqi, as agreed between them. This ensures that each group has access to its own grazing resources and hence prevents any potential conflict. The Fashekab and Hamedab groups are somewhat wealthier then the Sadenab. A key element in this is camel ownership, as camels provide a means of transport for Bedouin resulting in an increase in economic opportunities. Ownership of camels permits three to four people (almost exclusively men), along with equipment, food and water supplies, to travel into the hills with sheep flocks in excess of 100 animals for winter grazing. Not only does this improve the quality of sheep (hence raising lambing percentages), but it also reduces some of the grazing pressure in Wadi Allaqi. Camels can also be used to transport charcoal made from dead acacia wood in the hills whilst Bedouin are tending the sheep, back to Wadi Allaqi and even directly to Aswan for sale. There is a clear production advantage from owning camels. Significantly, both the Fashekab and Hamedab own large numbers of camels; the Sadenab do not. Hence, the Sadenab are denied these important production opportunities, and this shows in terms of relative wealth levels between the clans.

Regardless of the communities' relative wealth levels, earlier research in the area has shown that 
people possess a well-developed local (indigenous) knowledge of natural resources (Briggs et al. $1998 ; 1999)$. This is especially so in relation to the importance of different vegetation resources for livestock grazing and other purposes. An important shortcoming of previous work, however, is that it focused exclusively on male environmental knowledges (but see White 1994; Solway and Mekki 1999). Until now, the economic contribution of women to the Bedouin household economy in this area has been somewhat neglected. This reflects the dominant representation of men as the key economic actors in the area (see, for example, Hobbs 1990; 1998), and the very practical difficulty of people from outside the immediate family gaining entry to female spaces.

However, without doubt, women have had to take on greater responsibilities for livestock care in Wadi Allaqi itself. When the flocks are taken to winter grazing by men, significant numbers of sheep and goats are left behind to be cared for by the women. These include pregnant and lactating animals, young animals, as well as those that are sick. This may total 50 or more animals for an individual woman, and frequently her children, to look after. Since the creation of Lake Nasser, it has now become much more common for at least part, and usually most, of the household to remain permanently near to the lakeshore, in areas such as Wadi Allaqi. As it is the women of the households who have become more sedentary, largely due to the attraction of a reliable water supply from Lake Nasser, and now rarely go 'up-country' with the men, this has led to inevitable changes, particularly in relation to small livestock production. The responsibility for managing those sheep and goats kept around the Lake Nasser shoreline in the areas of more permanent settlement has mainly, although not exclusively, become a female and child activity, even at those times when men may be present.

The research for this study was carried out as a longitudinal survey over a period of 12 months. Four extended family focus groups of Bedouin were selected and each was visited at least once per month by a team of researchers, comprising at least three people. The meetings comprised indepth conversations, sometimes lasting over two hours, with each of the groups. Although there was an agreed checklist of topics to be covered, the emphasis of the discussions was very much on informality. Hence, we describe these meetings as conversations rather than interviews. Bedouin are uncomfortable with the use of tape-recorders and note taking, thus records of each meeting had to be written up after leaving each group. A result of this is that it has not been possible to record long passages of the words of our research participants.
As the meetings took place, the degree of trust and openness increased, in both directions, and hence the research team became more confident of the quality of information collected. Within each of the Bedouin groups, both men and women participated in the discussions, but in separate spaces.

\section{The development of women's local environmental knowledges}

Women generally are more strongly supportive than men towards the process of sedentarization in the downstream Wadi Allaqi area, and few women still accompany men into the hills for winter sheep grazing and/or charcoal-making. This has been a decision made largely by the women themselves, by choosing to engage in new household reproduction activities in the vicinity of the lakeshore, taking advantage of a reliable water supply, as well as improved grazing and soil resources associated with the relatively new resource of the lake. A consequence is that many men are absent from downstream Wadi Allaqi for periods of several weeks at a time whilst they are upstream, or whilst they are visiting Aswan to the north for business or family reasons. Hence, the responsibility for small livestock production in Wadi Allaqi itself increasingly rests with women. For them, however, the attraction of a secure water supply in Wadi Allaqi easily outweighs the burden of greater responsibilities they take on with the livestock. Consequently, women's lives have increasingly become more oriented by necessity towards those areas and environments in the immediate vicinity of the settlements within Wadi Allaqi. As a result, women's environmental knowledges are becoming more spatially restricted than those which many men possess. Men's knowledges are constantly being mediated by experiences and wider contacts with people elsewhere in the desert, as well as with contacts and experiences in the urban environments of Aswan and other Nile Valley towns to the north. Even within Wadi Allaqi itself, it is the men who are more likely to meet and talk to travellers and visitors to the area. Hence, a combination of long-standing social practices, restricting women's access to information in a wider world, and the much more recent, more restrictive personal geographies experienced by women as they have become sedentarized in Wadi Allaqi has meant that their environmental knowledges have become by necessity much more localized.

This has had an important influence on both access to, and the management of, grazing resources. The consequence of these more restricted geographies is that those animals for which they have responsibility are limited only to the grazing resources by 
Table 1 Main livestock feed types/sources used by women in downstream Wadi Allaqi

\begin{tabular}{|c|c|c|}
\hline Name & Description & Availability \\
\hline $\begin{array}{l}\text { Nageela (in Arabic) (includes } \\
\text { Fimbristylis bis-umbellata; } \\
\text { Eragirstis aegyptica; Cyperus } \\
\text { pygmaeus; Crypsis schoenoides) }\end{array}$ & $\begin{array}{l}\text { Collective name given to four grass and } \\
\text { herb types which grow close to the lake } \\
\text { shore after inundation }\end{array}$ & $\begin{array}{l}\text { Between November and May, as the } \\
\text { annual lake level recedes }\end{array}$ \\
\hline $\begin{array}{l}\text { Toroba (in Arabic) (Glinus } \\
\text { lotoides) }\end{array}$ & $\begin{array}{l}\text { A ground cover plant growing close to } \\
\text { the lake shore after inundation. It can } \\
\text { be grazed on site, or collected, dried } \\
\text { and used at a later time }\end{array}$ & $\begin{array}{l}\text { Between November and May, as the } \\
\text { annual lake level recedes }\end{array}$ \\
\hline Shilbeika (in Arabic) (Najas spp.) & $\begin{array}{l}\text { Aquatic vegetation which is collected } \\
\text { from the lake shallows, dried and stored } \\
\text { for later use, especially during the } \\
\text { drought season }\end{array}$ & All the year round from the lake \\
\hline $\begin{array}{l}\text { Tamarisk (abl or tarfa in Arabic) } \\
\text { (Tamarix nilotica) }\end{array}$ & $\begin{array}{l}\text { A tree or bush which grows quite } \\
\text { profusely in Wadi Allaqi, from which } \\
\text { new leaf growth is used for feed as it } \\
\text { has not yet become too salty }\end{array}$ & $\begin{array}{l}\text { All the year round, but the recent high levels } \\
\text { of the lake have inundated most of the trees } \\
\text { and bushes, either killing them or making } \\
\text { them unavailable because of deep water }\end{array}$ \\
\hline $\begin{array}{l}\text { Acacia (generically sant in } \\
\text { Arabic) (Acacia raddiana (sayal } \\
\text { in Arabic); and Acacia } \\
\text { ehrenbergiana (salam in Arabic)) }\end{array}$ & $\begin{array}{l}\text { A hardy desert tree from which leaves } \\
\text { and sometimes fruits are taken for feed }\end{array}$ & $\begin{array}{l}\text { Very few exist in downstream Wadi Allaqi } \\
\text { and therefore not a major source of feed in } \\
\text { this area (unlike in upstream areas where it } \\
\text { can be locally important) }\end{array}$ \\
\hline $\begin{array}{l}\text { Handal (in Arabic) (Citrullus } \\
\text { colocynthis) }\end{array}$ & $\begin{array}{l}\text { A small prostate plant producing hard } \\
\text { melon-like fruits containing seeds which } \\
\text { can be dried and fed to livestock }\end{array}$ & $\begin{array}{l}\text { Not very common in downstream Wadi } \\
\text { Allaqi, but is cultivated by some Bedouin } \\
\text { (and called gawerna in Arabic) }\end{array}$ \\
\hline Purchased feed & $\begin{array}{l}\text { Mainly maize or sorghum grain purchased } \\
\text { from Aswan (average price LE1.50 per } \\
\text { kilo), but sometimes also sacks of dry or } \\
\text { stale bread (variable prices) }\end{array}$ & $\begin{array}{l}\text { All the year, but this represents a large cost } \\
\text { input }\end{array}$ \\
\hline
\end{tabular}

Note: LE1 (one Egyptian Pound) equalled about US\$3.50 at the time of the research.

Source: Bedouin interview materials from Wadi Allaqi, April 2000-April 2001.

the lakeshore. Unlike most men, women do not have access to alternative winter grazing in the hills. For those livestock dependent all the year round on downstream Wadi Allaqi grazing resources, this has led to a dependence on a relatively narrow range and limited quality of feed types, with implications for both livestock health and productivity. As a consequence, women have had to develop new knowledges about grazing materials available for the small livestock under their care in Wadi Allaqi. On the face of it, there is a reasonable mix of grazing resources and feeds available, ranging from grasses grazed in situ, through aquatic vegetation collected from the lake and then dried, to green material from trees and shrubs such as tamarisk and acacia (Table 1). Interestingly, the seven grazing and feed types listed in Table 1 are made up of both old and new resources as far as the women are concerned, in other words a combination of old and new environmental knowledges. For example, although acacia is well known to Bedouin, both women and men, as a source of feed for livestock, it is not very abundant in downstream Wadi Allaqi and therefore of limited importance here. In any case, Bedouin generally only use acacia as a feed source of last resort, as acacia leaves are still usually available in the severest of droughts long after other feed sources have disappeared. Similarly, handal was well known to the women before they settled in Wadi Allaqi, but, like acacia, it is not profuse in the downstream area (although some have chosen to cultivate handal as a feed, but only on a limited scale). The presence of these two feed types in the range of resources available raises an interesting question as to the extent to which these are residual knowledges still held by women, and knowledges that are becoming relatively less important. If they become unimportant as feed for small livestock 
production in Wadi Allaqi, then they may indeed eventually become forgotten in the context of the new physical environment and its new opportunities.

Nageela (a collective Arabic word for grasses and herbs) is also recognized by women as having been present in upstream areas, growing in response to winter rain. However, as sheep and goat production was less important as a female activity at that time, because men were around more often, women had less reason to be familiar with this as a feed resource. In any case, any such knowledge needed to be modified in the context of the downstream area, because nageela responds not to scarce annual rainfall, but to the annual inundation cycle of Lake Nasser. Whereas in the upstream areas, such as Ungat and Eigat (see Figure 1), the appearance of nageela is both temporally and spatially unpredictable, in the downstream area it is highly predictable as the lake level recedes and the saturated lakeshore emerges. It is, however, only available for part of the year and, in any case, it is grazed off very quickly by livestock, leading to the complaint that there is never enough of it. Nonetheless, nageela is seen to have good nutritional qualities for livestock.

The other four feed types represent new feeds about which women have had to develop new knowledges. Like nageela, toroba only becomes available when the lake level drops, thus enabling such plants to grow on the exposed lakeshore. However, it is only available for grazing from about November until May/June at the most. Given grazing pressures in the area, much of this vegetation has little opportunity to establish itself and hence to produce any significant biomass. By April/May, temperatures are such that scorching of young growth becomes a serious problem. There are, however, serious difficulties in using toroba as feed material. Although it can be grazed in situ on the immediate lake shore immediately after the lake has retreated, women prefer to collect and dry it, as it has a somewhat bitter taste for animals when wet. It is always new toroba that is grazed or collected, because, as it matures, it becomes increasingly bitter and poisonous for sheep due to the higher content of toxic components in the plant's mature stage. Even fresh toroba can be problematic when wet, as it can cause diarrhoea. When toroba is cut or dies and is exposed to the sun the toxic components decompose. Sheep and goats will eat mature toroba if they are hungry as a last resort, but this can cause excessive thirst. The result can be that animals will drink too much and this in turn can cause respiratory problems. We were told that one Fashekab man lost around 100 sheep a few years ago after they ate mature toroba. It should be noted that the availability of toroba is not consistent throughout Wadi Allaqi. Although toroba grows profusely in Wadi Um Ashira and also in the Sadenab area, it is far less common in Wadi Quleib.

Shilbeika is another feed resource previously completely unknown to Bedouin, but about which they have developed a thorough practical knowledge. This aquatic vegetation is plentiful and, importantly, is available throughout the year. However, its collection is difficult and tiring work, especially in winter when the water is cold, and large amounts of wet vegetation provide only relatively small amounts of dry feed matter. After being harvested from the lake, it is dried, because if not, it can cause diarrhoea, and therefore loss of condition, among sheep. Bedouin women are well aware of this problem. Nonetheless, they sometimes feed sheep with small amounts of shilbeika in a wet condition if they have no dry material available as an alternative, a clear indication of feed pressures in the area. This is an especially important issue for the Sadenab, the poorest of the communities, who are particularly dependent upon shilbeika as a grazing resource. Shilbeika is collected all year round, even when plenty of alternative grazing is available, and it is dried before being stored. It is particularly used in the drought season. It is important that the shilbeika is grazed or cut because when the lake retreats, exposed shilbeika rots and can prevent new nageela from coming through, thus reducing available grazing areas.

Likewise, tamarisk is another new feed, but only the young shoots of this tree are collected, as the older, more mature material is too salty and therefore unpalatable for livestock. However, even this resource has come under pressure since 1999 with the unprecedented high lake levels completely inundating all the tamarisk stock and therefore not being accessible to small stock for several months at a time. It is only those trees that remain emergent above the water near to the lakeshore that are currently available, and it is only from these that fodder can be collected. In any case, tamarisk is not a particularly favoured feed as it gives milk a poor taste and leads to a steady loss of livestock condition. An additional problem of tamarisk, when it is growing away from the lake water, is that its canopy creates shade and so reduces the amount and quality of undergrowth that could be used for grazing. Even more importantly, decayed leaf drop from tamarisk increases the salt content of the area immediately surrounding the tree or bush, with inevitable consequences for other vegetation types.

The difficulties with these feeds are varied, and relate to availability, quantity and quality. It is clear, therefore, that reliance on locally available and 
accessible vegetation for grazing and collected feed is problematic. One solution to this is to buy in feed from Aswan, either grain or unused dry bread. This is an expensive solution, as the prices are relatively high and there is the added problem of transporting these feeds the $180 \mathrm{~km}$ back to Wadi Allaqi. For women there is the added complication that they rarely visit Aswan themselves and so are very reliant on men to bring this back for them. For these reasons, in reality, this source is seldom used by Bedouin women.

It is clear that, in support of their new and added responsibilities for small livestock production in Wadi Allaqi, women have had to develop and modify their environmental knowledge base. Far from being reactionary, they have been proactive, in many cases using trial and error experimentation. Women have not relied on men for environmental knowledge acquisition, but have developed such knowledges themselves in the context of their changing economic roles since becoming increasingly sedentarized in Wadi Allaqi. This has especially been the case with regard to the use of the aquatic shilbeika, for example. Indeed, there are grounds for supposing that, because of the daily demands for animal feed, some women may now have developed a better knowledge and understanding of these resources than some men.

\section{The socio-economic contextualization of women's indigenous environmental knowledges}

Developing and possessing such environmental knowledges, and the opportunity to use them to their fullest extent, may however be two rather different things. It is apparent that such knowledges, to make any sense, must be contextualized and grounded in the wider socio-economic environment, as other factors and constraints may serve to reduce such opportunities. For example, women already have a full workload, such that looking after sheep and goats constitutes only one of many livelihood activities. Such responsibilities include caring for children and ill and very elderly relatives, cooking, cleaning, water and firewood collection, and even the relocation of tents within Wadi Allaqi in response to lakeshore movements. The relative importance of all these activities varies between households, and between different time periods in the same household. Small livestock tending may therefore not always be given consistently top priority. Importantly, girls help out with these various household activities when they are old enough; indeed, evidence from this study suggests that one of the main areas in which both girls and boys help out with household reproduc- tion is in looking after sheep and goats on a daily basis. For boys, this is part of the growing-up process in terms of learning how to care for small animals in anticipation of them joining adult men in taking sheep to the hills for winter grazing, once they themselves reach the age of about 14-15 years or so. However, children are not always as careful as they might be in their care of sheep. In particular, little management of shoreline grazing is demonstrated, and some Bedouin suggest that the grazing pressures around the lakeshore are exacerbated by the relative lack of regular adult supervision.

The issue is further complicated by the structure of households which influences the extent to which women value small livestock production as economic activities within the context of the whole household economy. This is even the case among those women who have developed an effective local environmental knowledge, but the ways in which that knowledge may be put to use may be influenced and mediated by their social context. An important discriminating factor concerns the marital status of older women. Those women who have husbands consistently give a lower priority to sheep and goat caring, in comparison to widows, regardless of their depth of environmental knowledge in relation to livestock feeds. Widows have far less security and therefore generally see sheep and goat production as a key way of sustaining themselves. Women with husbands have access to a greater range of economic activity and income (for example, sheep, goats, camels, charcoal, medicinal herbs etc.). Access to these production elements is very much dependent on access to the wider desert beyond Wadi Allaqi, the very thing that has increasingly become much more clearly defined in recent years as a male geographic space. Widows are generally excluded from this world. Sometimes a widow may have a male relative who is willing to take some of her sheep with his own flock to access winter grazing in the hills. The result is that widows, through necessity, have to make greater use of locally produced environmental knowledges in their daily management of livestock. Widowhood not only creates problems of social exclusion, but is part of a wider process of economic marginalization, and, because of only a limited range of economic opportunities, this marginalization necessitates a keener use of indigenous knowledges to survive than those women who may have a greater access through a husband to a wider range of economic opportunities.

Women are only too aware of the inadequacies of feed resources in the area, and their consequent impacts on lambing percentages and quantity and quality of milk, as well as on the general health and condition of livestock. Naturally available 
grazing is neither profuse nor always present in downstream Wadi Allaqi. However, many women recognize the benefits to be gained from diversifying feed types for livestock. Because women have become geographically constrained to Wadi Allaqi, their environmental knowledges of this area have had by necessity to become more specialized, and in some instances have become deeper than those held by some men. Many have a firmer grasp of the area's resource opportunities, and particularly constraints, for small livestock management and production. Once again, marital status is important; even though those women with husbands rarely go to the desert themselves, they do nonetheless have access to the productive capacities of the desert through their husbands. Widows do not have this option, and therefore have to make the best of the natural resource base available to them in downstream Wadi Allaqi. Widows are in an ambiguous position in society as regards gender roles in that they are forced from necessity to adopt tasks normally only available to men, and that other married women may eschew.

Unsurprisingly, men in the communities are divided in their views over women's changing roles in relation to livestock production and resource management. All are agreed about the economic importance of women in the tasks they perform, but not all are wholly comfortable with some of the recent changes. Whereas the notion of women caring for small groups of sheep and goats is generally accepted by men, this is only in the context of providing milk for household consumption. All recognize that the realities of present circumstances, where sheep are taken for winter grazing away from Wadi Allaqi, has resulted in management changes which have necessitated women taking on greater responsibilities, but this is an empowerment which is not always universally welcomed. Interestingly, views were expressed suggesting that some years ago the idea of women taking greater responsibility for looking after significant numbers of sheep and goats was considered quite negatively, but changed economic circumstances have brought about these changes. This led to speculation that other aspects may also change in the next few years. For example, at the moment it is culturally forbidden for Bedouin women to milk animals or to sell animals themselves to outsiders, which clearly includes making visits to markets. Some men, however, were prepared to consider the possibility of such changes in the future. Others were clearly not as well disposed, suggesting that changing gender roles in terms of production is creating uneven tensions within the communities, in that some women were becoming 'too independent for their own good'.
This supposed independence in a sense can be seen in other ways. In general, women in Wadi Allaqi are more interested in cultivation than are men, and widows more than married women. Women themselves are perhaps developing a different construction, or knowledge, of their immediate environment, a knowledge which sees the cultivation of small farms as an additional way of exploiting local resources, of spreading risk and of trying to improve the household's material circumstances. At a practical level, because women are now virtually permanent residents of the downstream area, they are on hand to see through the cultivation cycle. But it is more than this, to the extent that women appear to have a sharper awareness of the consequences of the grazing limitations of the area. Cultivation therefore provides an additional hedge against risk. Culturally, some men perceive cultivation as not 'work for a Bedouin [man]'. All this would seem to point to women, and especially widows, being a group more open to cultivating feed crops in support of livestock, and further developing local environmental knowledge through their own experiences. What becomes apparent is that if women's household roles had not changed in relation to new settlement patterns and to different economic opportunities, then women would not have developed new environmental knowledges.

There is, however, a danger with this argument in seeing women as an homogenous group and of promoting a gender stereotype of women as cultivators and men as livestock herders. Reality is more complex. It is not only women, but also those poor families, more generally, who do not have access to camels for desert transport, who are constrained to the immediate environment in downstream Wadi Allaqi and the limited resources it offers. In this context, of the three main clans in the area, the Sadenab, with limited resources, constitute the group which rarely goes to the desert for winter grazing or charcoal-making. Of all the Bedouin in the area, it is families from this clan who demonstrate the greatest interest in cultivating small farms near to the lakeshore, regardless of gender or female marital status. This would appear to be because of an awareness of the pressure on the local environment and the need to utilize local resources in a wider context. Following this line of argument, a key issue would appear to be household wealth, which, in turn, has an important influence on the gender relations which exist within particular households and clans. Because of the constraints imposed by being less well-off than other groups, Sadenab people have had to develop local environmental knowledges which may be different to those of other wealthier groups, and which clearly reflect local circumstances. 
Without doubt, women see the cultivation of animal feed as only a supplement to existing feed types to ensure a longer-term stabilizing of animal quality at least effort for women. Indeed, such feed cultivation is rarely at the expense of food crop production. Widows in Wadi Allaqi are more interested and engaged in cultivation than other women, perhaps due to the necessity of providing economic diversification for themselves, something that is available to married women through their husbands' wider geographical access to the resources of the desert and the markets of Aswan. They are certainly more likely to engage in cultivation, although more to supplement their own food needs rather than producing feed for livestock. A key reason for this emphasis on food needs is that they argue that not enough animal feed can be cultivated to make the labour input worthwhile, that 'within days sheep have eaten two months of crop growth'. A combination of growing such crops on small plots of only a few square metres in some cases, and therefore producing only very small amounts, and then feeding this material to the livestock, without mixing with other feed types, explains this. Nonetheless, when feed crops are produced, however modestly, three favoured feed types are likely to be grown. Maize (zora in Arabic) and sorghum (dura) have the advantage of not only producing a grain, but also green material from the discarded stalk. Such grains are widely used by sheep producers in the Nile valley to fatten animals and are generally seen to give a good return. Lucerne (berseem) is also widely used in the Nile valley, although the view is that sheep fed only on lucerne produce less meat than those on a mixed lucerne and grain diet. The combination of these cultivated feeds and naturally available grazing at different times of the year in Wadi Allaqi is seen as a way of improving sheep quality. However, the availability of labour to cultivate these crops constitutes a major constraint.

There are also other important problems to be addressed. Firstly, a dependable water supply is crucial to women committing scarce labour resources to cultivation. There needs to be a guarantee that the water supply will not disappear once cultivation is underway. At the foot of both Wadi Um Ashira and Wadi Quleib, where each joins Wadi Allaqi, a number of hand pumps have been installed by Aswan Governorate. However, even after only a few weeks' service, some became unusable. They are also physically tiring to use, such that women and older children can only use them for relatively short periods of time. An alternative arrangement has been to dig wells from which water is then pumped onto the cultivated plots through lengths of hosepipe by diesel-driven pumps. Part of the problem of site selection for cultivation is predicting lakeshore changes. Sites with flat gradients are inappropriate in that lakeshore movements in such areas can be extensive with the result that plots can be easily inundated, and then, when the lake retreats again later in the year, the same plots can be left with dry wells with the lakeshore some 8-10 km distant. The most appropriate sites, therefore, are located on steeper gradients at the edge of Wadi Allaqi, preferably at the junctions with side wadis, including Wadis Um Ashira and Quleib. At such locations, water is usually available in wells for up to three months after the plot has been established, hence ensuring that there is a sufficiently long growth and maturation period for crops.

Another common complaint among women related to the difficulty of keeping sheep and particularly goats off their growing crops, something they have experienced for some time with regard to their existing cultivation efforts. Some use cut tamarisk tree branches as a fencing material, but this tends to encourage the use of smaller plots because of the large amount of woody material needed to protect successfully a large plot from animal incursions. There is the added problem that, once in situ, it is very hard and time-consuming work to move this type of fencing material to a fresh site or plot. A solution devised by some Bedouin women is to use old fishing nets supported by tamarisk posts as fences around cultivated plots. This has the advantage of being light and flexible to use, and whereas some animals may push their way through even some of the thickest tamarisk fences, they are far less willing to risk becoming entangled in fishing net.

Once again, it is the poorer women, frequently widows, who are likely to be more positive towards embracing changes that may contribute to improving sheep productivity. Wealthier women, or at least women with access to a greater range of economic output through marriage, are less positive. Ironically, what may seem to be an empowering move of women taking charge of resources and of making a positive contribution to household income, may instead be seen to be an unplanned activity of last resort by widows in particular. At the time of writing, two women (from the Sadenab group), both widows, have taken up some of these ideas and are experimenting with them. If successful in their cultivation efforts, this could have wider implications for the confidence that Bedouin women in Wadi Allaqi have in their abilities to contribute to the household economy. However, another interpretation in the community is that this is an act of desperation undertaken by widows, an act driven by poverty and not by any 
particular desire for empowerment. Even if the first interpretation prevails, this more 'strategic gender aim' (Moser 1989), that other women in the community may follow the lead of the Sadenab widows, is likely to take longer than might be expected.

A potentially important part of women's empowerment is the development of economic production directly for the market to generate a greater cash income. Although the origin of sheep (whether they are from the desert or the Nile valley) is an important factor in the level of market price, it is clear that the type of feed is at least equally as important. Sheep from Wadi Allaqi are therefore penalized twice. Firstly, desert sheep (ghanam bishari) consistently attract a lower price than valley sheep (ghanam baladi), seemingly regardless of condition; and, secondly, Allaqi sheep tend to be at the poorer end of condition of desert sheep, reflecting the poor nature of the grazing and feed on which they are raised. Bedouin women are not particularly aware of the nature and extent of these price differentials, reflecting their lack of participation in sheep marketing. However, after discussions of these differentials, some women accepted that improved feed would improve productivity and therefore price. The problem of how women access markets still remains, however. Although some women do trade small animals in the main markets in Aswan and Daraw, such women are few in number, and significantly they are Nile Valley residents and are not Bedouin. The cultural taboo of Bedouin women selling in the market remains a significant constraint and is likely to do so for some time to come. The market is still overwhelmingly a male space and whatever changing gender roles have occurred in the context of small livestock grazing and production in areas like Wadi Allaqi, no such changes have occurred in the market places of the Nile Valley for Bedouin women. Although social and cultural attitudes in the market place may be changing and women's roles in the livestock economy may be broadening, there are still distinct and important cultural issues which militate against this. Participation by women is still limited to those from the Nile Valley, and, among this group, largely to those who have few other means of survival, especially widows and divorcees. The prospect of Bedouin women from the desert selling their own sheep in the markets of Aswan, Daraw or elsewhere cannot be contemplated at this point in time. Therefore, if Bedouin women are to sell sheep, they are going to have to be wholly reliant on male family to do this. However, this may not be an issue for many, as sheep are typically seen as a household asset. Women may be responsible for looking after those sheep left in Wadi Allaqi, but few, if any, women see those sheep as exclusively their property. If the quality of those sheep is improved, and they start to command higher market prices because of this, then that will represent a significant contribution by women to the household economy. The problem, however, remains for those who are widowed and may not have such male family support.

\section{Conclusions}

The economic role of Bedouin women in Wadi Allaqi has changed considerably over the last few years, and especially so with increased sedentarization. The changes have been challenging in that women have had to develop two new sets of knowledges and skills. One has been to look after and maintain larger numbers of sheep and goats than they had done previously, and the other has been to develop knowledges about grazing resources that can be used to support those livestock. Without doubt, the changed gender roles associated with such sedentarization have had an important impact on the accumulation and development of new environmental knowledges by women. Moreover, such developments do not suggest a static, conservative and unchanging approach to environmental knowledge, indeed quite the opposite. Such knowledges can be seen to be fluid, dynamic and ever-changing, almost with an internal dynamism that is forever capable of being reworked and showing a willingness by women to evaluate and accumulate new knowledges and information for themselves (see Agrawal 1995; Bebbington 1993; Briggs et al. 1999).

A further interesting observation from the results concerns how gender intersects with both social and economic status. It tends to be widows, as well as women from poorer households, who have developed the more acute local environmental knowledges. This appears to have been done as a coping strategy, perhaps even a survival strategy in some cases. In that sense, the increased empowerment that might be seen among women in Wadi Allaqi, through their greater contribution to the household economy, may be less to do with choice and may be more to do with necessity.

However, perhaps more importantly have been the ways in which gender relations have been reworked, posing interesting questions. Conceptually, there is a significant difficulty in disentangling women's gender-driven socio-economic roles from that of the wider household. Approaches based on WID strategies are likely to be less successful in an environment where work is undertaken in the interests of the household, rather than just specifically 
for women. In Wadi Allaqi, although some women possess their own sheep (as part of a dowry, for example), these sheep may be taken by men for winter grazing as part of the total household flock. That is, although women know that they have their own animals, in practical terms, women's sheep are not seen as something separate from the overall household resource. In a sense, this reinforces the necessity of a GAD approach, which is sensitive to the interests and roles of both men and women. This necessitates a further examination of gender relations in different environmental conditions to understand more fully the roles of women and men in different situations.

It is also necessary to consider the differences in environmental knowledges between women and men in a wider sense than just related to small livestock production. Such results can inform more effective policy formulation, by drawing upon both women and men's understanding of the environment and resources in order to develop sustainable development that is owned and directed by various members of the communities involved. The changing role of women in the livestock market-place also deserves further examination in order to gain a sense of future possibilities. Thus, in addition to considering gender roles and environmental knowledges in other rural and desert locations, it will be necessary to examine whether Bedouin women, whose families have relocated to towns and cities in the Nile Valley, can enter into the livestock economy, or if this activity must still be mediated by men.

\section{Acknowledgements}

We wish to thank the Department for International Development for their financial support for this research through their Academic Links and Gender and Development programmes, and the British Council for their support over a considerable number of years for the collaborative link between the University of the South Valley in Aswan in southern Egypt and the University of Glasgow in the UK. We also wish to thank Professor Ahmed Belal, the Director of the Unit for Environmental Studies and Development, University of the South Valley, for his support in this project, but, most importantly, the Bedouin women and men who patiently took the time to talk with us. Thanks are also due to Mike Shand for producing the map.

\section{References}

Adams W, Potkanski T and Sutton J 1994 Indigenous farmermanaged irrigation in Sonjo, Tanzania Geographical Journal $16017-32$
Agrawal A 1995 Dismantling the divide between indigenous and scientific knowledge Development and Change 26 413-39

Bebbington A 1993 Modernization from below: an alternative indigenous development? Economic Geography 69 274-92

Bell M 1979 The exploitation of indigenous knowledge or the indigenous exploitation of knowledge: whose use of what for what? IDS Bulletin $1044-50$

Bellon M 1995 Farmers' knowledge and sustainable agroecosystem management: an operational definition and an example from Chiapas, Mexico Human Organisation 54 263-72

Boserup E 1970 Women's role in economic development Allen and Unwin, London

Briggs J 1995 Environmental resources: their use and management by the Bedouin of the Nubian Desert of southern Egypt in Binns T ed People and environment in Africa John Wiley, Chichester 61-7

Briggs J, Badri M and Mekki A M 1999 Indigenous knowledges and vegetation use among Bedouin in the Eastern Desert of Egypt Applied Geography 19 78-103

Briggs J, Badri M, Pulford I and Shaheen A S 1998 Indigenous and scientific knowledges: the choice and management of cultivation sites by Bedouin in Upper Egypt Soil Use and Management 14 240-5

Briggs J, Dickinson G, Murphy K, Pulford I, Belal A E, Moalla S, Springuel I, Ghabbour S I and Mekki A M 1993 Sustainable development and resource management in marginal environments: natural resources and their use in the Wadi Allaqi region of Egypt Applied Geography 13 259-84

Bryceson D F ed 1995 Women wielding the hoe: lessons from rural Africa for feminist theory and development practice Berg Publishers, Oxford

Chowdhry G 1995 Engendering development? Women in Development (WID) in international development regimes in Marchand M H and Parpart J L eds Feminism/postmodernism/ development Routledge, London 23-41

Desai V and Potter R B eds 2002 The companion to development studies Arnold, London

Hardin G 1968 The tragedy of the Commons Science 162 1243-8

Hobbs J 1990 Bedouin life in the Egyptian wilderness The American University in Cairo Press, Cairo

Hobbs J 1998 Bedouin conservation of plants and animals in the Eastern Desert, Egypt Unpublished conference paper

Jackson C 1993 Doing what comes naturally? Women and environment in development World Development 21 1947-63

Jewitt S 2000 Unequal knowledges in Jharkand, India: deromanticizing women's agroecological expertise Development and Change 31 961-85

Lamers J P A and Feil P R 1995 Farmers' knowledge and management of spatial soil and crop growth variability in Niger, West Africa Netherlands Journal of Agricultural Science 43 375-89

MacKenzie F 1995 Selective silence: a feminist encounter with environmental discourse in colonial Africa in Crush J ed Power of development Routledge, London 100-12

Maddox G, Giblin J and Kimambo I N 1996 Custodians of the 
land: ecology and culture in the history of Tanzania James Currey, London

McCabe J T 1990 Turkana pastoralism: a case against the tragedy of the commons Human Ecology 18 81-103

Moser C 1989 Gender planning in the Third World: meeting practical and strategic gender needs World Development 17 1799-825

Pretty J 1994 Alternative systems of inquiry for a sustainable agriculture IDS Bulletin 25 37-48

Reij C, Scoones I and Toulmin C 1996 Sustaining the soil: indigenous soil and water conservation in Africa Earthscan Publications, London

Sillitoe P 1998 A place against time: land and environment in the Papua New Guinea Highlands Harwood Academic Publishers, Amsterdam
Solway J and Mekki A M 1999 The socio-economic system of Wadi Allaqi Allaqi Project working paper 33

Tiffen M, Mortimore M and Gichuki F 1994 More people, less erosion: environmental recovery in Kenya John Wiley, Chichester

Varley A 2002 Gender, families and household in Desai V and Potter R B eds The companion to development studies Arnold, London 329-34

White T 1994 Overgrazing in Wadi Allaqi Allaqi Project working paper 25

Young K 1993 Planning development with women: making a world of difference Macmillan, London

Young K 2002 WID, WAD and GAD in Desai V and Potter R B eds The companion to development studies Arnold, London 321-25 